Доц. д-р Мирослав Пендароски

МИТ универзитет, Факултет за психологија, Скопје

\title{
ГРУПНА СОЦИЈАЛНА РАБОТА СО АДОЛЕСЦЕНТИ: НЕКОИ ДИНАМИЧКИ НАЧЕЛА
}

UDK: 364-785.24-053.6

\section{Вовед}

Секоја практика која се занимава со одредена проблематика од научно-апликативен аспект пред себе има низа предизвици, потешкотии, проблеми. Во исто време, таа со себе носи низа предности, специфичности, вредности и свои силни страни, особено во поглед на одредена популација со која се занимава и која ја има за себе како централна целна група. Па така и групната социјална работа како чедо на психологијата на малата група и клиничката психологија, од една страна, и типичната социјална работа и поширокиот социјален супстрат, од другата страна, пред себе си поставува мноштво предизвици, прашања, дилеми. Овој метод има широка примена токму благодарејќи на својата дијалектична и комплексна природа која во себе ја содржи мудроста на малата група која овозможува индивидуален приод пред и во групата, а во исто време со себе ја носи силата на поширокиот општествен концепт и контекст на кој односната индивидуа припаѓа. Во таа специфична ситуација на грижа како за индивидуата (без која групата ја губи својата смисла) така и за поширокото влијание на нејзината работа и дејството врз околината и општеството, воопшто, групната социјална работа предничи во можноста од широка примена врз низа проблематики, прашања, популации. Не попусто постојат мноштво определби, класификации, категоризации на групната социјална работа која секогаш во себе го носи никулецот на психосоцијалниот 
Ревија за соиијална политика, год. 8, бр.11/2 Скопје, ноември 2015

метод опфаќајќи ја главнината на социопсихолошките прашања во едно динамичко секојдневие.

Како што истакнува Доневска (1999), социјалната работа (а со тоа и групната социјална работа како еден од главните нејзини методи) секогаш претставува операционализација на стремежите и стратегиите на социјалната политика (Доневска, 1999, стр. 166; според: Пендароски, 2012, стр.95). Ваквата определба само ја зацврстува нејзината широкоопфатна структурна и динамичка природа на дејствување, како катализатор на сеопштите општествени движења, политики и вредности на едно општество. Самиот факт дека многу теоретичари, практичари и истражувачи наведуваа дузина можни класификации (Toseland \& Rivas, 1995; Preston-Shoot, 1987, 2007; Petterson, 1981; Bertcher, 1994; Zastrow, 2010 и др.) нека посведочи за значајноста на овој метод во социјалната работа. Според овие и други теоретичари и практичари постојат најразлични групи: третмански групи; групи за решавање задачи; групи за самопомош; групи за личен развој итн. Без разлика колкав и да е бројот на ваквите групи, останува непобитниот факт дека сите тие во себе ја носат двополната суштина на психосоцијалната промена:

1) психолочко-индивидуалниот и

2) сочијално-групниот аспект.

Со ваквата определба се истакнуваат двата круцијални аспекти на групната социјална работа. Едниот, психолошкиот го обработува и согледува секогаш идиосинкратичниот, автентичен и уникатен сегмент на психосоцијалното функционирање на една единечна индивидуа во својата комплексна психолошка димензија, се разбира во поглед на аспектот кој е содржан во целта на односната групна работа. Тоа би можело да се подведе под терминот психосоцијален третман, затоа што во тој поим лежи суштината во индивидуална смисла на групната социјална работа - индивидуалната промена со цел подобрување и на околината низ взаемодејството околинапоединец. Вториот аспект се однесува на секогаш круцијално врзаниот концепт кон индивидуалниот, групниот, социјалноеколошкиот, контекстуалниот. Вредноста на групната социјална 88 
работа за пошироката заедница се крие токму во овој аспект кој не ја држи оваа метода затворена во аисторискиот, асоцијалниот и безконтекстуалниот индивидуалистичко-солипсистички притвор, откинувајќ́ ја од местото каде што припаѓa - нејзината околина, социјалната заедница. Напротив, преку овој свој еликсир групната социјална работа ја раскрилува индивидуата презентирајќ ја на фидбекот на околината и понудувајќи ѝ низа можни решенија кои доаѓаат од нејзината можност да сподели, да поттикне, да поддржи.

Но, предизвиците на групната работа не застануваат на меѓата на научниот метод туку се распостелаат кон популациите со кои таа може да се занимава. Се чини, како никој друг метод, групната работа им прилега на адолесцентите, како од психолошки така и од социјален аспект. Имено, оваа популација изобилува со разнобразие од хаотични насоки во својот психофизички и психосоцијален развој. Наоѓајќи се на двомеѓето меѓу возрасноста и детството оваа популација е раскината меѓу личните барања, желби, потреби, можности, свесност и дејствителност и социјалните надојдени барања и одговорности кои неретко се косат во суштина со првонаброените. Во таквиот фрустрирачки дијаден обрач, младиот човек неретко се наоѓа во бессознание од психосоцијален аспект за тоа како да постапува, во што да верува, како да функционира итн.

Самиот период на адолесценција е дефиниран како време на бури и ветришта, на големи промени и дисбаланси во секој поглед, како психофизички, биолошки, физиолошки, психосоцијално и аксиолошки (вредносно). Токму затоа, групната социјална работа претставува место каде тој може да се пронајде бивајќи опкружен со на себе еднакви, слични и мотивирани луѓе да го истражуваат истото што и тој самиот - својата личност, идентитетот, светогледот, професионалниот правец и др.

Многу видови групи се погодни во овој период како медиум преку кој адолесцентот може да се развива, но и да ги решава своите како транзиторни така и релативно трајни психосоцијални регресии и фиксации. Третманските групи, на пример, можат да му понудат вистинска групна поставеност за целисходно и специфично 
Ревија за соиијална политика, год. 8, бр.11/2 Скопје, ноември 2015

професионално и стручно водено работење на одредена прецизирана тема (зависност, асоцијално поведение, агресивно однесување, слаб училишен успех, проблеми во љубовно-социјалната интерперсонална сфера итн.). Групите за самопомош (иако со доза на резерва и повремена контрола) ќе овозможат самоевалуативно и исполнето со доверба споделување на интимни аспекти на своето суштествување со на себе блиски и по возраст и по размислување, но и по вредности поединци. Во таквите групи отсуствува проблемот на справување со авторитет од проста причина што тој не е присутен во облик на водач или терапевт. Групите за личен развој, исто така, ќе овозможат единствено и креативно доживување и развивање на својата личност во себесвесна и автентична единка во дослух со своите и барањата на околината. Кој групен облик и да се одбере и во какви просторновременски и социјално-контекстуални услови, секако ќе биде од корист во работата со адолесцентите. Ваквите групи може, а и пожелно е да се создаваат поблиску до природните и посакувани локации и окружувања на адолесцентите: во училиштата, во социјалните клубови, во спортските клубови, во општински заедници и маалските групи. Но и во специфичните институции доколку се работи за адолесценти со социјално-воспитни или други проблеми (во установи за социјално-запуштени деца и млади; во казненопоправни домови; во установи за згрижување деца и млади без родителска грижа; во установи за ментално здравје и др.).

Сепак, пред да се пристапи кон сериозна психосоцијална групна работа со адолесценти, пожелно е да се истакнат и запознаат некои специфики на одредени динамички аспекти на групната работа, воопшто, и групната работа како засебно искуство во работата со адолесценти. Некои од спецификите од кои неколку понатаму во текстот ќе бидат повеќе елаборирани се следниве :

- некои групни улоги;

- конфликти го група;

- групна поддршка;

- улогата на водачот;

- групна кохезија и др. 
Мирослав Пендароски: Групна соиијална работа со адолесценти: некои...

Овие аспекти на групната структура и динамика произлегуваат од многуте специфики на адолесцентите во психолошка смисла: агресивноста произлезена од хормоналниот развиток и севкупниот психофизички развој и драстичните промени во таа смисла; непостојаноста во однесувањето и наглите и изненадни промени во општото расположение; склоноста кон депресивност и автодеструкција како резултат на недооформениот идентитет и дилемите околу себеси; сексуалните кризи на психосексуалниот идентитет и изборот на партнер; родовите улоги и доживувањето во својата заедница како машко, односно женско; сликата за себеси и нивото на самодоверба; системот на вредности; барањата на околината и сопствените потреби и идеали; ставот кон авторитетите; семејните односи и нивното сфаќање од страна на адолесцентот и низа други.

\section{I. Некои психосоцијални специфики на адолесцентниот период}

Како што беше посочено во воведот, адолеснетниот период изобилува со низа специфичности и од нив произлезени потреби од стручна адаптација на групната работа, согласно некои феномени кои може да се јават во групната работа. Имено, некои автори наведуваат повеќе можни специфични состојби, појави и процеси кои се јавуваат како материјал кој не смее и не треба да биде занемарен при работа со оваа популација. На некој начин, самиот факт дека работиме со група адолесценти наговестува дека се работи за активност со вулнерабилни индивидуи. Така, некои автори (Reamer, Siegel, 2008) наведуваат низа знаци на психосоцијални пореметувања на рамнотежата во поведението и самочувството кои можат да бидат патоказ дека се работи за специфична адолесцентска група. Некои од нив се следниве:

- ниска себепроценка;

- намален успех и отсуства од училиште; 
Ревија за соиијална политика, год. 8, бр.11/2 Скопје, ноември 2015

- отпор спрема секој вид авторитети (родители, наставници, полиција итн.);

- бегање од дома;

- погрешен избор на другари;

- импулсивно поведение (примери : плукање, пцовки, ризично однесување итн.);

- запаѓање во неприлики со кршење закони;

- депресивност;

- злоупотреба на алкохол и дроги;

- социјално изолирање;

- пореметувања на нагонот за хранење (прејадување, булимија, анорексија и др.);

- самоповредување и др. (Reamer, Siegel, 2008, стр. 1).

На овие можеме уште да додадеме и: анксиозни пореметувања, асоцијално и антисоцијално однесување, социјален аутизам итн. Доволно е само да се биде свесен за самите развојни промени и кризни периоди за да се разбере адекватноста на еден специјален приод во групната работа со овие млади лица и без да се навлегува во социјално-патолошките сфери на однесувањето. Когнитивните аспекти на адолесцентскиот период носат пред младиот живот низа нови когнитивни развојни шеми, програми и мисловни алгоритми кои со надоаѓањето на етапите на формалнологичкото и апстрактното мислење само стануваат уште понеразбирливи за сѐ уште неголемиот човек-адолесцент. Таквите барања проследени со инхерентност на овој период, т.н. когнитивен егоиентризам, т.е. ставот и уверувањето дека тие знаат најдобро и се единствено исправни во мислењето, прави од адолесцентите своевидни недозреани сезнајковци кои се убедени во својата когнитивна грандиозност. Емоционалниот развој е уште една посебна приказна која бара адаптација на цела нова група емоции и чувства кои адолесцентот веќе може да ги разликува, дефинира и разгледува, но сѐ уште не може вистински да ги доживува, а уште помалку да ги разбира. Сето тоа подразбира фрустрација која произлегува од конфликтите меѓу амбивалентните чувства за себеси и другите, промените во поларитетите меѓу: агресивно и балансирано, тажно и 
екстатично, депресивно и манично, експресивно и латентно итн. Ваквиот хаос во афективната сфера предизвикува неадекватно и често неизвесно и импулсивно поведение. Некаде се среќаваат следниве парови на поларитети кај адолесцентите :

1. Бунтување против контролата на возрасните - Потреба од насочување; 2. Желба за блискост - Страв од интимност; 3. Тестирање на границите - Перцепџија на граниџите како симбол на грижа и сигурност; 4. Когнитивен индивидуализам/ егоиентризам - Потреба од припаѓање; 5. Желба за водство Одбегнување одговорност и други.

И на крај, психосоцијалниот аспект од развојот, кој многу подробно го разработија Роберт Хавихрст (Havighurst, 1961) и Ерик Ериксон (Erikson, 1968) во своите развојни психосоцијални концепции, подразбира процес на развој на чувството за сопствениот идентитет и целисходноста на сопственото субјективно суштествување, својата цел, како и свесноста за специфичен тип на психолошки и социјални потреби (потреба за автономија, економска независност, потреба за идентитет, социјално припаѓање, социјално признание и др.)

Сиве овие особености изнудуваат многу внимателен приод и специфични групни методи и техники во работата со адолесцентите и адаптирање на групната работа. Но, за да се види кој вид/тип на групна работа и кои принципи треба да се почитуваат при групна социјална работа со оваа популација, неопходно е да се осврнеме на некои фундаментални феномени на групната структура и динамика, а кои се силно поврзани со некои од наведените особености на адолесцентите. 
Ревија за соиијална политика, год. 8, бр.11/2 Скопје, ноември 2015

\section{II. Феномени на групната структура и динамика кои се фундаментални при работа со адолесцентите}

Генерално определено, во групната работа постојат два општи ентитети :

1) групна структура и

2) групна динамика.

Во праксата овие два ентитети се преклопуваат и се заемнозависни. Всушност, структурата не е статички феномен туку динамички, постојано променлив систем. Според најбазичните сфаќања, структурата претставува однос и поврзаност меѓу деловите на некоја целина.

Ајдуковиќ истакнува дека некои од основните сегменти на групната структура се: улогите, составот на групата, подгрупите (Ajdukovic, 1997, според: Пендароски, 2012, стр. 221). Тука се и групните норми како дел од структурата на групата. Всушност, групната структура може да се гледа и како типична димензија на динамиката, токму поради фактот што покрај составот, големината на групата, улогите во неа, таа се однесува и на интеракциите и односите меѓу составните делови. Од друга страна, групната динамика изобилува со мноштво групни процеси кои ја чинат нејзината суштина.

Според Пендароски (2012), со анализа на класификацијата на Рот (1988) може да се дојде до следниве четири големи групации /процеси во групата :

- Формациско-нормативни процеси - усвојување на норми, механизми на однесување, групни улоги итн.

- Интеракциско-оперативни процеси - основни облици активности во извршување на задачите на групата : конформирање, соработка, натпревар, конфликт итн. 
- Структурално-интеракциски процеси - процеси на специфично структурирање на групите и односи на соработка и конфликт кои се јавуваат од нив: подгрупи, коалиции, дијади, тријади, конфликт, соработка, моќ на влијание итн. и

- Интеракциско-егзекутивни - процеси на донесување одлуки важни за остварувањето на групните цели кои произлегуваат од специфичните структурални и динамички карактеристики кои се јавуваат во групната функција (според: Пендароски, 2012, стр.211-212).

Од оваа широка категоризација произлегуваат двете најопшти димензии на динамиката:

1. Структурално-динамичките во кои спагаат: формацисконормативните и структурално-интеракциските и

2. Динамичко-интерактивните во кои спаѓаат: интеракцискооперативните и интеракциско-егзекутивните (според: Пендароски, 2012, стр. 212).

Во првата општа димензија се оние процеси кои произлегуваат од самата структура (големина на група, подгрупи, норми, улоги итн.) и интеракциите кои произлегуваат од таа структура, но не се однесуваат директно на изведбата на групата (исполнување на целите на групата, извршување на групните задачи итн.) иако тие индиректно влијаат врз групниот перформанс преку специфичните односи, интеракции и комуникации меѓу членовите на групата. Во втората димензија влегуваат пак типично динамичните процеси насочени директно кон, т.н. фокус на задача, а не на социјалниот фокус и директно придонесуваат во егзекуцијата, т.е. исполнувањето на целите, задачите, активностите на групата. Тие процеси се функционални, оперативни и методски.

Ваквиот воведен приказ ни овозможува да ја градиме практичната групна работа со адолесцнетите базирајќи ја врз научностручните теоретски и апликативни основи за двата големи динамички процеси: социјалните и оперативните. Тоа значи дека оформувањето, нормирањето и перформирањето на групата се 
Ревија за соиијална политика, год. 8, бр.11/2 Скопје, ноември 2015

заснова на свесноста за значајноста на двата аспекта, бидејќи без било кој од нив групната работа нема да ги исполни целите: социјализација, личен развој, третман итн.

\section{II.1 Некои од посебните димензии на групната динамика на кои е важно да се обрати внимание}

\section{Улоги во група}

Групните улоги некои автори ги подразбираат како однесување кое е резултат на интеракиијата меѓу: ситуационите фактори, сознанијата, потребите, ставовите и особините на интерперсоналното реагирање на поединецот (Sarbin, 1954). Други автори пак како функиија која ја презема поединецот како член на груnа (Milovanovic, Stakic, 1991, стр. 189). Трети пак како споделено очекување за функиијата на членот во соодетната група (Toseland\&Rivas, 1995, стр.82). Во која и дефиниција да погледнеме ќе забележиме дека улогата е специфичниот начин на очекувано однесување кое произлегува од некоја формална и структурирана групна улога. Тоа бара од членот на групата да се придржува до одредени норми на однесување за да ги исполни барањата вметнати во посебната улога, а без чие остварување не би се исполниле групните цели, за кои групата всушност и постои. Кога се адолесцентите во прашање, групните улоги се од огромно значење од повеќе аспекти: адолесцентот сѐ уште трага по својата индивидуална и општествена улога, тој не ја остварил својата професионална улога итн. Сето ова како и сето погоре опишано како психосоцијални, емоционални и когнитивни специфичности на оваа популација го прави динамичен концептот на почитување на групните улоги. Адолесцентот неретко нема дисциплина да додржи во улогата ниту пак адекватно и континуирано и доследно да ги извршува дејствата кои природно произлегуваат од соодветната улога. Особено неколку специфични улоги се важни за водачот на групата, а кои можат да ја нарушат групната структура и динамика, да придонесат кон создавање подгрупи и кланови па дури и да предизвикаат терминација, „смрт“ на групата. Некои од тие улоги се следниве: 
- улога на „жртва“;

- улога на „аутсајдер“;

- улога на „саботер“ и други.

\section{Улога на „жртва“}

Улогата на „жртва“ е премногу ризична и значајна за одржливоста и продуктивноста на групата, а од особено значење е за добрата атмосфера. Пендароски (2012) смета дека оваа улога произлегува од дејството на напаѓање на одреден член на групата од страна на другите членови и е најчесто несвесен механизам на проекција на елементите, појавите, кои членовите на групата кај себе не сакаат да ги признаат или пак не можат да ги препознаат. Овој чин овозможува тие да ја намалат тензијата во себе и во целата група (според: Пендароски, 2012, стр. 330). Според Клајн и соработниците (1996) појавата на жртвување се јавува како последица на два основни фактори:

1) потребите на групата;

2) потребите и карактеристиките на жртвата (според: Klein, 1996).

Најчесто жртвувањето се случува со избор на погоден член од групата кој поседува особини какви што се: различен е од другите, припадник е на малцинство, не се вклопува, интровертен е и молчаллив, има дијаметрално различни ставови од другите, не е доволно адаптиран итн. Кај адолесцентите ваквите особености дополнително го отежнуваат функционирањето во групата. Имено, треба да се внимава и водачот навремено да детектира потенцијална жртва меѓу адолесцентите во групата бидејќи тоа може да има далекусежни последици. Една од опасностите е дека адолесцентотжртва ќе влезе во, т.н. декомпензација, т.е. ќе се повлече, ќе се затвори, ќе „избега“ од целокупниот групен процес, а со тоа нема да ги исполни очекувањата од улогата и целите на групата. Адолесцентот-жртва може да развие став на резигнација кон групата и да го зацврсти ставот на неприфаќање авторитет олицетворен во улогата на водачот, а што далекусежно по пат на класично и 
Ревија за соиијална политика, год. 8, бр.11/2 Скопје, ноември 2015

оперантно условување ќе доведе до генерализација на условниот рефлекс во вид на негативна реакција при секое следно групно искуство. Бидејќи во групата неговото однесување било следено со казна, т.е. со процесот на проекција и стигматизација, адолесцентот во таа улога развива чувство дека во секоја слична ситуација неговото однесување ќе биде казнувано, а тој исмеван и отфрлан. На психолошко поле, последиците од оваа улога може да бидат и катастрофални и терминални, т.е. да создадат некакво невротско нарушување од депресивен или анксиозен вид, а во случај на депресивност и проследено со суицидни идеи, токму заради сликата за себе која се развива а која е сочинета од низа негативни ставови и чувства за себеси. Водачот е должен да ја следи групната динамика и да препознае потенцијално жртвување, да го осуети и да го разрешува во самата група. Постојат и низа индикатори кои укажуваат дека постои жртвување:

- кога еден или повеќе членови не можат да се вклопат или пак тешко се вклопуваат;

- кога членот бара заштита надвор од групата;

- $\quad$ кога некој член постојано е против ставовите на другите, кога е незадоволен и налутен итн.;

- $\quad$ кога се стекнува впечаток дека еден од членовите претставува објект на исмевање, задевање, омаловажување, напаѓање;

- кога некој член има интенција постојано да се бори за наклоноста на другите;

- кога членот е отфрлуван, неприфаќан во групните активности, кога е недопадлив за другите итн.;

- кога често се спротивставува на водачот и/или на другите членови;

- кога е пасивен, доцни, незаинтересиран е и сл.;

- кога е осамен во групата, кога покажува речиси аутистично однесување итн.;

- кога му е потребно двојно повеќе време за да почне да се отвора;

- $\quad$ кога доцни со исполнувањето на групните задачи итн. (според: Пендароски, 2012, стр. 336). 
Можноста од појава на оваа негативна улога се зголемува со зголемување на бројот на членови во групата. Џустен (2011) во своето истражување открил резултати кои ја потврдуваат оваа претпоставка.

Резултатите се изложени во Табела 1.

\begin{tabular}{|l|l|l|}
\hline $\begin{array}{l}\text { Големина на } \\
\text { групата }\end{array}$ & $\begin{array}{l}\text { Процент на појава } \\
\text { на жртвувањето во } \\
\text { група }\end{array}$ & Број на проверки \\
\hline Група од 3 членови & $29.8 \%$ & 1000 \\
\hline Група од 10 членови & $68.1 \%$ & 1000 \\
\hline
\end{tabular}

Табела 1. Процент на појава на жртвување кај две групи (преземено и адаптирано од: Joosten, 2011, според: Пендароски, 2012).

Доколку се детектира оваа улога веднаш треба да се испита групната социјална функција, да се проверат интерперсоналните односи и единечната одговорност на секој од членовите и нивната искрена посветеност на целите на групата. Евентуално, доколку водачот е за тоа обучен психолошки, да се пријде кон длабинска анализа на, т.н. потсвесна динамика на групата, т.е. да се увидат притаените процеси кои се латентни, а кои можат од која било причина да се поврзани со жртвувањето на еден член на групата.

\section{Улога на „саботер“}

Саботерот одигрува уште една интересна улога која не е атипична за адолесцентната популација. Напротив, заради социо-психолошкиот контекст на созревање и оформување на психосоцијалните димензии на идентитетот, адолесцентот е често присутен гостин во оваа улога, т.е. таа е речиси адекватна на неговиот парадоксален мотив да биде присутен во група, а во исто време да ја бојкотира, саботира и оневозможува. Погоре во текстот тоа беше презентирано како конфликтна потреба од припадност и 
Ревија за соиијална политика, год. 8, бр.11/2 Скопје, ноември 2015

спротивставување на секаква структура и авторитет. Адолесцентот ја мрази структурираноста, редот, одговорноста и оттаму саботерската улога е честа појава во адолесцентски групи. Таквите саботери редовно нешто приговараат, нешто не им одговара, го нарушуваат редот и структурата, не ги исполнуваат своите должности кои произлегуваат од улогата на членови на групата, а воедно се обидуваат да ги одвлечат другите членови од интересот за групата, исполнувањето на групните цели, кои треба да бидат и индивидуални цели на секој член на односната група. Всушност, како што истакнува Мек Милан (2009) дека саботерот се опира и спротивставува на групните цели и идеи заради свои лични мотиви и причини. Според неа, тој член секогаш има своја, скриена агенда со која на другите им наметнува други цели, различни од групните и со одредени постапки ја оддалечува групата од нивно исполнување занимавајќи ја со сосема други и неповрзани теми, на тој начин одбегнувајќи да се конформира (McMillan, 2009, 2011). Мек Милан оваа негативна улога ја сместува во редот на, т.н. блокерски, отежнувачки улоги кои го отежнуваат целокупното функционирање на групата. Некои особености на саботерот се следниве: потреба да ги осуетува предвидените задачи на групата и да блокира позитивни процеси; секогаш ги истакнува лошите страни на групата дури и кога се минорни; не се сложува со најголемиот дел од членовите или со целата група, а редовно тоа го прави со водачот на групата; незаинтересиран е; саркастичен и зајадлив; одбегнувачки се однесува и неодговорен е; премногу е самоуверен во сопствената исправност; постојано приговара и негодува итн. Но, честопати ваквиот профил на саботерот е само манифестен облик на прикривање на длабоката фрустрација, незадоволство, неретко депресивност и незадоволство од сопствената личност и компетенција. Едно од можните објаснувања е дека саботерот на овој начин несвесно или полусвесно се обидува да се наметне, да се допадне, зошто тој поседува неретко нарцисистичка црта на личноста доминирана од потребата да се допадне, да биде препознатлив и водач. Пендароски (2012) наведува дека постоењето на оваа улога укажува на низа недостатоци на групната структура и динамика : 
- слаба кохезивност во целата група или дел од неа;

- неискреност и затвореност во групата;

- слабо водство;

- групни цели кои не соодветствуваат со личните цели на членовите;

- недоволно сериозни членови на кои може да се додадат и: неадекватнен состав на групата; потиснати конфликти кои не се доразработени; премногу левтерен начин на лидерство и др.

Ваквите опасности се триплираат кога станува збор за адолесцентна група, со што се наметнува прашањето како да се постапи. Ајдуковиќ (1997) наведува неколку можни дејствија:

- поттикнување разговор во група околу темата - колку групните цели се поклопуваат со личните;

- да се поттикнат членовите да проговорат за тоа како ги доживуваат личните цели на другите членови и да го проценат нивниот напредок;

- преку воопштена изјава да му се пренесе порака на саботерот за тоа како групата го доживува и гледа неговото однесување (Ajdukovic, 1997, стр. 247, според: Пендароски, 2012, стр.377).

Сепак, оваа корисна согледба на Ајдуковиќ, не ја зема доволно предвид огромната улога на водачот на групата како една од причините ако не за јавување, тогаш за перзистирање на оваа улога. Водачот кој не е доволно авторитативен и демократичен во смисла да ги следи однесувањата, потребите, особеностите на сите свои членови и кој не поседува изграден сензибилитет за интуитивно препознавање на групната атмосфера, свесно или несвесно ја пропушта растечката димензија на саботерот кој пополека ги окупира околу себе другите членови, ги заразува со своите негативни идеали и од понесигурните меѓу нив прави сигурни партнери во еден долг процес на разнебитување на групната структура, а потоа и на динамиката преку умртвување на активностите, барање поддршка во саботажата и доближувањето до една друга опасна улога - 
Ревија за соиијална политика, год. 8, бр.11/2 Скопје, ноември 2015

паралелниот водач. Токму затоа, на оваа определба на Ајдуковиќ треба да и́ ги додадеме и следниве препораки:

- преиспитување на адекватноста на водачот и посебно неговата функција насочена кон одржување на групата и неговиот социјален фокус, т.е. неговата компетентност да ги одржува, развива и користи односите во групата;

- ако е потребно да се создаде атмосфера за повторно демократско избирање на формален водач од редовите на членовите. Оваа одговорност би можеле да ја преземат најодговорните членови или некој кој има авторитет меѓу членовите, а не е формален водач на групата (да се избегнува саботерот);

- $\quad$ водачот да го преиспита својот објективен став и перцепција кон групата и нејзината лична значајност за него итн.

\section{Конфликти во група}

Позната е наједноставната дефиниција која вели дека конфликтите претставуваат спротивставени мислења околу една иста работа/појава. Ваквата денотативна определба укажува на значајноста и индивидуалноста, субјективноста на извориштето на конфликтите - сопствената личноста, суета, гордост, став итн. Конфликтите во адолесцентски групи не се нешто кое треба да нѐ депримира и одврати од намерата да работиме со група адолесценти. $\mathrm{He}$, напротив, конфликтите се, всушност, пожелни затоа што ја отсликуваат природната состојба на нештата во периодот на бури и урагани, кога низ спротивставувањата на своето и туѓото се гради она кое ќе биде релативно трајно, идиосинкратично и автентично личноста. Конфликтите сами по себе не се ниту добри ниту лоши. Тие постануваат такви зависно од начинот на кој се разрешуваат. Денес се познати мноштво начини на нивно разрешување. Некои од нив се делат на : компетитивни и колаборативни (Петровска-Бешка), позитивни и негативни итн. Понекогаш за жал, во групите конфликтите, воопшто, и не се решаваат и тие остануваат темпирана бомба која во секој миг може во неврат да ја однесе сета групна 
структура и нормираност. Токму затоа, конфликтите треба веднаш да се решаваат, особено во работа со адолесценти кои долго не можат да ја додржат тензијата која настанува од непотрошената енергија, акумулирана од нараснатиот и потиснат конфликт кој катадневно ја триплира мрачната атмосфера и ја разјадува кохезијата. Всушност, и самото постоење на конфликти укажува на нарушена структура и намалена кохезија како и на влошена социјална димензија на групата. Честопати, групите кои се повеќе насочени кон задачи, а не кон односи, страдаат од конфликти заради тоа што долго не обраќале внимание на постоечките конфликти. Една позната шема на можни начини на разрешување на конфликти е следната прикажана на слика број 2.

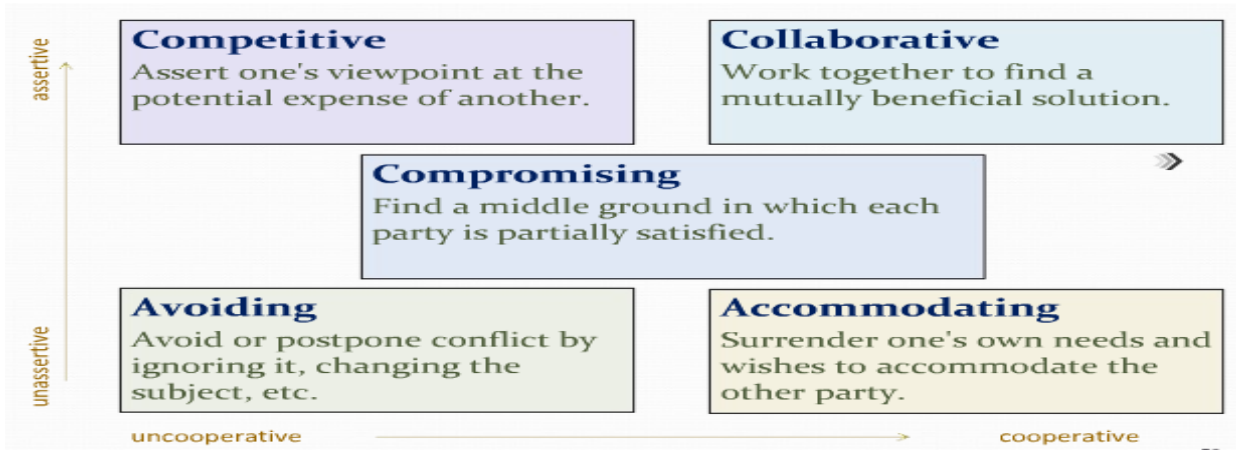

Слика 2. Приказ на можни начини на решавање конфликти.

Конфликтите во групите со адолесценти се подразбираат од самата смисла на овој развоен период, бунтовноста, револуционерноста и желбата за експериментирање кое просто произлегува од фактот што адолесцентот експериментира на полето на сопствената личност оформувајќ и ја под дејство на испробувањето на разните уоги, матрици, однесувања и идеи. Оттаму водачот треба да ја има предвид оваа вистина развиена околу конфликтната природа на самиот период и да се обиде да ја балансира со зголемена свесност за појавата играјќи на картата на развој на индивидуалните капацитети на секој посебен член-адолесцент во склоп на групата и со барање на заедничката основа која ги спојува сите членови, а која 
Ревија за соиијална политика, год. 8, бр.11/2 Скопје, ноември 2015

може да се огледа во поддршка на матриците на однесување и размислување својствено за овој период од животот.

\section{III. Начела, принципи, методи и препораки за групна работа со адолесценти}

Специфичноста на адолесцентниот период која со себе ја носи тежината на поставувањето на групните принципи, начела и норми во работа со оваа популација, придонесе во последниве две декади да се работи на стандардизација на групната работа со адолесценти. Пример за тоа се стандардите за групна работа со адолесценти поставени од страна на HACB/NASW (National Association of Social Workers, 1993), Американската асоцијација на социјални работници од кои некои се следниве:

Стандард 1. Социјалните работници треба да демонстрираат знаење и разбирање на адолесцентниот развој.

Стандард 2. Социјалните работници треба да демонстрираат разбирање за потребите на адолесцентите; да имаат пристап до институциите, организациите и сите ресурси во општеството кои даваат услуги за адолесценти и нивните фамилии; да бидат поборници за развој на потребните ресурси.

Стандард 3. Социјалните работници треба да демонстрираат знаење и разбирање на семејната динамика (NASW Standards for the Practice of Social Work with Adolescents, 1993).

Овде наведените само три стандарди се доволен доказ за тоа колку се посветува внимание на специфичноста на оваа популација и овој тип групна работа и колку социјалните работници (и сите други) кои работат со адолесценти во групен сетинг треба да бидат опремени со знаења и разбирања на специфичните развојни психосоцијални феномени. Таквите препораки содржани во стандардите се однесуваат на неколку најзначајни аспекти кои ние 104 
имплицитно ги споменавме погоре во текстот: познавање на развојниот период на адолесценцијата и сите специфики во психофизичка и социјална смисла; познавање, чувствување и разбирање на потребите на оваа популација, но и познавања на специјализираните институции и организации кои ги задоволуваат тие потреби и обезбедуваат сервиси за оваа популација.

Во овој контекст апликаивно е да се наведат принципите на Андреј Малекоф (Malekoff 2001,2002) кои се однесуваат на групната работа со адолесценти. Имено, Малекоф поаѓајќи од идејата дека институционалните видови на работа со оваа популација пред адолесцентите поставуваат низа ограничувања, норми, правила, дошол до заклучоци дека оваа популација има потреба од одредени насоки и принципи при групната работа. Малекоф ги наведува следниве седум принципи:

1) да се организираат групите водејќи се од потребите и желбите на адолесцентите, а не од дијагнозите и проблемите. Малекоф нагласува дека ваквиот приод кон потребите и желбите не е корисен само за да се постават целите и задачите на групата туку и да се дефинираат најкорисните методи и техники во групната работа;

2) да се структурира групата така да ја прифати индивидуата во целост, а не само како проблем. Малекоф истакнува дека група адолесценти претставува одличен контекст во кој може многу добро да се согледаат различностите и капацитетите на целата индивидуа;

3) да се интегрираат вербални и невербални активности во групната работа. Ова произлегува, како што потенцира Малекоф, од фактот дека е мошне неприродно да очекуваме од адолесцентите само да седат во група и да дискутираат. Младите луѓе имаат потреба да се движат, да го користат телото, да гестикулираат итн.;

4) да се децентрализира авторитетот и да се препушти дел од контролата на членовите на групата. Ваквиот маневар ќе ги зајакне членовите-адолесценти и ќе го зголеми нивното чувство на моќ, но и нивната одговорност и доследност. На 
Ревија за соиијална политика, год. 8, бр.11/2 Скопје, ноември 2015

овој начин водачот се растеретува од преголемата одговорност, а со тоа ја развива и групата адолесценти кои ги повикува и поттикнува на личен ангажман, активност, одговорност;

5) да се развива соработка и близина со значајни возрасни луѓе од најтесното опкружување на адолесцентот;

6) да се држи фокусот на две работи: на индивидуалната промена и на реформата на системот. Малекоф истакнува дека групните водачи треба да работат на промена на индивидуите кои ќе го менуваат општеството и ќе бидат негови активни и корисни членови;

7) да се разбере и почитува развојот на групата како клучен за развојот и промената (според: Sota, 2013).

Сите напоменати принципи претставуваат суштина во создавањето концепт согласно популацијата со која практикуваме групна работа. Пред сѐ, плени хуманистичката насока на гледање на членовите-адолесценти како целина, како феномен кој во себе содржи когнитивни, емоционални, бихејвиорални, но и социјални сегменти на неповторливото и оригинално единство - личноста. Таквото почитување на волевиот и демократски аспект на личноста на членовите на групата придонесува промената, третманот кој се случува на индивидуално, психолошко поле да се преточи, проектира и аплицира кон промена на пошироката средина преку пример на идентификација на која новите адолесценти ќе се огледуваат и од која ќе учат. 


\section{Литература}

Ajdukovic, M. (1997) Grupni pristup u psihosocijalnom radu. Zagreb : Drustvo za psiholosku pomoc.

Bertcher H., Kurtz L.F., Lamont A.(ed.). (1999) Rebuilding Communities : Chalenges for Group Work. New York, London, Oxford : The Haworth Press.

Biehal, N., Clayden, J., Byford, S. (2000) Preventive work with teenagers: evaluation of an adolescent support team.

Доневска, М. (1999) Социјална политика и социјална работа. Зборник на текстови. Скопје: Филозофски факултет, 165-175.

Доневска, М., Балшиќевска, М. (2010) Моќ во мала група. Годишен зборник на Филозофски факултет. Скопје: Филозофски факултет, 549-564.

Klain, E. (1996) Grupna analiza: grupna analiticka psihoterapija. Zagreb: Medicinska naklada.

Klein, A. (1970) Social work through group process. New York: School of social welfare, State university of New York at Albany.

Konopka, G. (1983) Social group work: A helping process (3-rd edition). Englewood Cliffs, NJ : Prentice-Hall, Inc.

McMillan, E. (2011) Group Dynamics. Encyclopedia of Business, $2^{\text {nd }}$ edition, 19.

NASW (1993) Standards for the Practice of Social Work with AdolescentsPrepared by the Social Work with Adolescents Standards Work Group. Approved by the NASW Board of Directors.

Пендароски, М. (2012) Влијанието на групната динамика врз остварувањето на целите во групната социјална работа. Скопје: Филозофски факултет.

Пендароски, М. (2011) Односот со адолесцентот во наставата - еден комплексен процес. Скопје: Просветно Дело, 2011, 4.

Пендароски, М. (2011) Средношколскиот клас како социо-психолошка група. Скопје: Просветно Дело, 2011, 3, 51-64.

Preston-Shoot, M. (1992) On empowerement, partnership, and authority in groupwork practice : A training contribution. Groupwork, 5 (2), 5-30.

Preston-Shoot, M. (1989) Using contracts in group work. Groupwork, 2 (1), 3647.

Preston-Shoot, M.(1987) Effective groupwork. London : MacMIllan.

Reamer, F. G. (2008) How Social Workers Help Struggling Teens. National Association of Social Workers.

Sota, M. (2013) Review of Group Work Principles with Adolescents and their Practical Implementation in Education Environment in the Framework of Potentials Perspective. The Contribute of Andrew Malekoff.Journal of Educational and SocialResearch, Vol. 3 (2) May 2013. 
Stakic, J., Milovanovic, M. (1991) Metode socijalnog rada. Beograd: Strucna knjiga i Savez drustva socijalnih radnika Srbije.

Toseland, R.W., Rivas, R.F. (2005) Introduction to group work practice (5-th edition). New York : Allyn \& Bacon.

Toseland, R.W., Jones, L., Gellis Z. (2004) Group dynamics. In C. Garvin, L. Gutierrez, M. Galinsky (Eds.). Handbook of social work with groups (pp. 13-31). New York and London : The Guilford Press.

Toseland, R., Rivas, R. (1995) An introduction to group work practice ( $2^{\text {nd }}$ edition). Needham Heights, Massachusets: Allyn and Bacon.

Toseland, R., Rivas, R. (1984) An introduction to group work practice. New York : MacMIllan. 